\title{
Indonesian Continuing Professional Development Implementation: Knowledge Development Aspect of Yogyakarta Senior Secondary School Mathematics Teachers
}

\author{
Theresia Veni Tri Nugraheni \\ Atma Jaya Catholic University, Indonesia \\ theresiaveni@gmail.com \\ Jailani \\ Yogyakarta State University, Indonesia
}

\begin{abstract}
Continuing Professional Development (CPD) contributes to teacher competencies, teaching practice quality, and student achievement. Based on a literature review, we found that there were three aspects of CPD. The CPD aspects that we found were: knowledge development; skill development; and knowledge dissemination. In this study, we focused on describing: (1) the CPD implementation, and (2) the barriers faced by senior secondary school mathematics teachers in Kulon Progo Regency in conducting the aspect of knowledge development. This type of study is descriptive research using a mixed method with convergent parallel design. The research subjects were all senior secondary school mathematics teachers in Kulon Progo Regency who participated in The Indonesian Teacher Competency (Uji Kompetensi Guru) in 2015 and 33 teachers were selected. Data were collected through a questionnaire, documentation, and interviews, and analysed using descriptive techniques. The results showed that the CPD implementation in the aspect of knowledge development of senior secondary school mathematics teachers in Kulon Progo Regency was poor. The greatest barriers experienced by teachers related to conducting the aspect of knowledge development were an overwhelming workload, lack of selfmotivation, and inadequate place and time. Based on these findings, we suggested that teachers needed to be helped to develop their understanding and awareness of how CPD can improve their competencies, teaching practice quality, and student achievement. We also suggested that the government and stakeholders should encourage and facilitate teachers to participate actively to CPD activities that reach out teachers' need.
\end{abstract}

Keywords: Continuing Professional Development, implementation, barriers

\section{Introduction}

Developing quality education cannot be realized properly by just improving curriculum, infrastructure or facilities, without developing teacher quality. Developing teacher quality is important because teacher quality has large effects on student achievement (Darling-Hammond, 2000; Rockoff, 2004; Stronge, Ward, Tucker, \& Hindman, 2007; Buddin \& Zamarro, 2009). Teachers are the centre of reform as teachers must apply high standards in the classroom practice. Therefore, the efforts to develop teachers' competencies are continuously needed.

Teachers' competencies can be defined as skills, knowledge, attitudes, beliefs, and behaviours applied during work as a professional teacher. Studies also have reported that 
teacher knowledge contributes to student achievement (Hill, Rowan, \& Ball, 2005; Tchoshanov, 2011). Therefore, improving teacher knowledge is needed.

Continuing Professional Development (CPD) can develop teachers' competencies. Studies have reported that CPD can improve teacher performance, teacher competencies, and teaching practice (Powell, Furey, \& Scott-evans, 2003; Shah, Khan, \& Shamed, 2015). However, teacher professional development and training in several regions in Indonesia has been reported as not yet satisfactory (Andriani, 2012; Rahmat, Amprasto, Riandi, \& Sutarno, 2011; Sujianto, 2013; Wibowo \& Jailani, 2014).

Hence, this present study focused on describing (1) the CPD implementation and (2) the barriers faced by Indonesian senior secondary school mathematics teachers in Kulon Progo Regency, Yogyakarta in improving knowledge development.

\section{Theoretical Background}

\section{Concept of Continuing Professional Development}

The term of professional development or continuing professional development is commonly used to describe teachers' activities designed to enhance their competencies. Based on the definitions of CPD explained by educational experts, (Bailey, 2011; Bubb \& Early, 2007; Collin, van der Heijden, \& Lewis, 2012; Day, 2002, Guskey \& Sparks, 2000; Mitkovska, 2010), we summarized that Continuing Professional Development has three keywords as follows:

i. Continuing, the learning experiences and activities continuously gained or conducted by teachers during their professional practice as teachers;

ii. Professional, the learning experiences and activities that focus on teachers' competencies and performance, as they become professional teachers and carry out their professional duties according to determined competencies standards;

iii. Development, the teachers learning experiences and activities with the purpose of improving teachers' competencies, teachers' teaching practices, and student achievement.

Regarding to the concept of CPD, Desimone (2009) propose a basic model as conceptual framework of professional development (see Figure 1). 


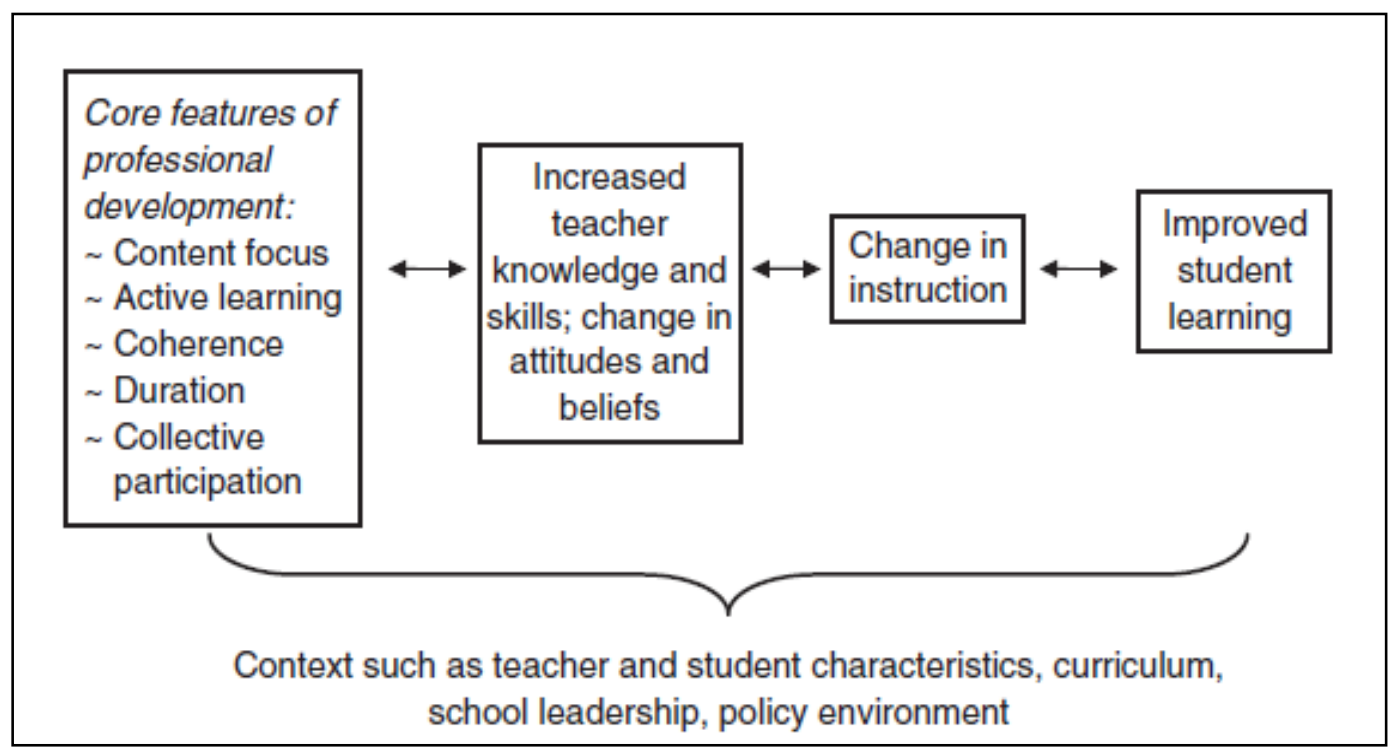

Figure 1. Conceptual Framework of Professional Development

(Desimone, et. al, 2009, p. 185).

Based on Figure 1, professional development noticing of core features of professional development can: (1) increase teachers' knowledge and skills, change teachers' attitudes and beliefs; (2) teachers using those knowledge, skills, attitudes, and beliefs can change teaching practice quality; and furthermore, (3) improving teaching practice quality effects student achievement.

\section{Aspects, Indicators and Activities of Continuing Professional Development}

We synthesized experts' theory and presented the CPD's aspects, indicators, and activities in Table 1 .

Table 1

The CPD's Aspects, Indicators, and Activities

\begin{tabular}{lll}
\hline \multicolumn{1}{c}{ Aspect } & \multicolumn{1}{c}{ Indicator } & \multicolumn{1}{c}{ Activity } \\
\hline $\begin{array}{l}\text { Knowledge } \\
\text { Development }\end{array}$ & $\begin{array}{l}\text { Professional reading } \\
\text { (Opfer \& Pedder, 2010; Ozdemir, } \\
\text { 2013) }\end{array}$ & $\begin{array}{l}\text { Reading literature related to } \\
\text { mathematics content. } \\
\text { Reading literature related to } \\
\text { teaching, learning, or education. }\end{array}$ \\
& $\begin{array}{l}\text { Formal education } \\
\text { (Ozdemir, 2013) }\end{array}$ & $\begin{array}{l}\text { Continuing formal education to } \\
\text { magister or doctoral degree. }\end{array}$ \\
& $\begin{array}{l}\text { Professional training } \\
\text { (Opfer \& Pedder, 2010; Desimone, }\end{array}$ & $\begin{array}{l}\text { Taking part in workshops, seminars } \\
\text { or conferences. } \\
\text { Taking part in professional learning } \\
\text { Porter, Garet, Yoon, \& Birman, } \\
\text { 2002; Ozdemir, 2013; Ministry of } \\
\text { communities. } \\
\\
\text { of National Education, 2010a; Ministry }\end{array}$ \\
&
\end{tabular}




\begin{tabular}{|c|c|c|}
\hline Aspect & Indicator & Activity \\
\hline \multirow[t]{2}{*}{$\begin{array}{l}\text { Skill } \\
\text { Development }\end{array}$} & $\begin{array}{l}\text { Teaching practice development } \\
\text { (Croft, Coggshall, Dolan, Powers, \& } \\
\text { Killion, 2010; Desimone, Porter, } \\
\text { Garet, Yoon, \& Birman, 2002; } \\
\text { Ozdemir, 2013) }\end{array}$ & $\begin{array}{l}\text { Developing mathematics teaching } \\
\text { media. } \\
\text { Developing mathematics learning } \\
\text { assessment. } \\
\text { Identifying students' misconception } \\
\text { Conducting individual educational } \\
\text { research. }\end{array}$ \\
\hline & $\begin{array}{l}\text { Teachers collaboration } \\
\text { (Croft, Coggshall, Dolan, Powers, \& } \\
\text { Killion, 2010; Desimone, Porter, } \\
\text { Garet, Yoon, \& Birman, 2002; } \\
\text { Ozdemir, 2013) }\end{array}$ & $\begin{array}{l}\text { Conducting action research in groups. } \\
\text { Conducting Lesson Study. }\end{array}$ \\
\hline \multirow[t]{2}{*}{$\begin{array}{l}\text { Knowledge } \\
\text { Dissemination }\end{array}$} & $\begin{array}{l}\text { Scientific paper publication } \\
\text { (Ministry of National Education, } \\
\text { 2010a; Ministry of National } \\
\text { Education, 2010b) }\end{array}$ & $\begin{array}{l}\text { Publishing scientific paper (literature } \\
\text { review educational paper, } \\
\text { educational research paper, or } \\
\text { mathematics textbook). }\end{array}$ \\
\hline & $\begin{array}{l}\text { Presenter at workshops, seminars or } \\
\text { conferences } \\
\text { (Opfer \& Pedder, 2010; Ministry of } \\
\text { National Education, 2010a; Ministry } \\
\text { of National Education, 2010b) }\end{array}$ & $\begin{array}{l}\text { Presenting educational paper based } \\
\text { on literature review or research. }\end{array}$ \\
\hline
\end{tabular}

\section{Method}

This type of research was descriptive, using a mixed method approach, with a convergent parallel design. The collectingof data using convergent parallel design was conducted simultaneously and both quantitative and qualitative data were compared, linked, merged, and the results were used to focus on the research problem (Creswell, 2012). The research subjects were all Indonesian senior secondary school mathematics teachers in Kulon Progo Regency Yogyakarta, who participated in The Indonesian Teacher Competency (Uji Kompetensi Guru) in 2015 and a total of 33 teachers comprised the sample. The collection of data was conducted through questionnaires, documentation, and interviews. The details of the research subject are as follows: 33 teachers participated in CPD implementation and the CPD barriers questionnaires, while 28 teachers participated in CPD documents review, and 15 teachers participated in interviews.

The CPD implementation data was obtained through quantitative data based on the results of questionnaires and the qualitative data based on the result of interviews and documentation. The qualitative data analysis used a descriptive technique, while the 
quantitative data analysis performed a categorization process. The qualitative data analysis used data reduction, data display, and conclusion techniques (Miles \& Huberman, 1994). The CPD implementation barriers data was obtained through quantitative data based on the result of questionnaire and qualitative data based on the result of interviews.

\section{Results and Discussion}

\section{The CPD Implementation in Knowledge Development Aspect}

Regarding the CPD implementation with the aspect of knowledge development, the questionnaire data indicates that more than $90 \%$ teachers (32 out of 33) could improve their energy in conducting CPD, there was not one teacher in the very good category, and it was only $3.03 \%$ teacher ( 1 out of 33 ) in the good category (see Figure 2 ).

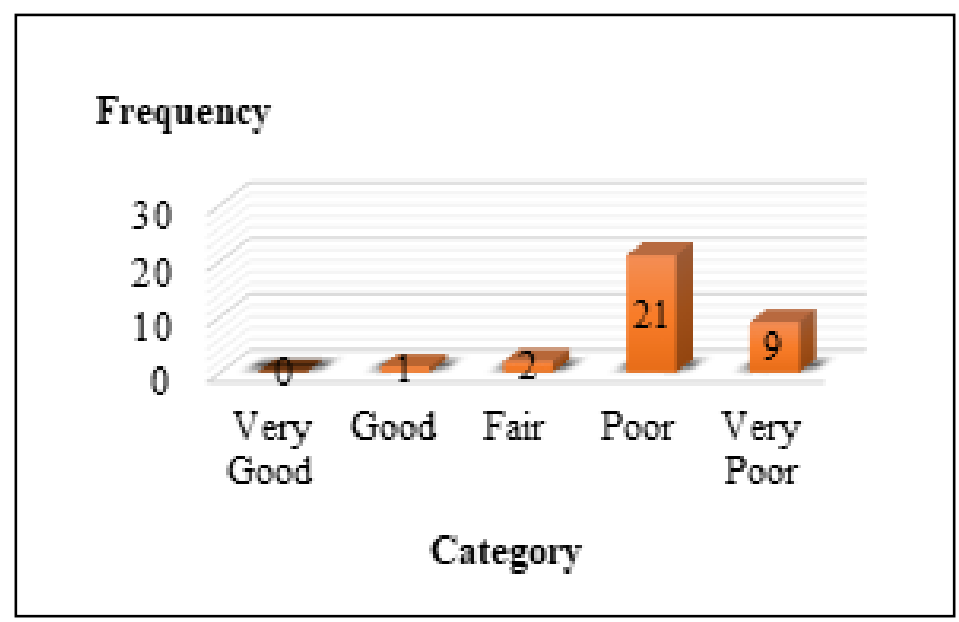

Figure 2. The numbers of teachers conducting CPD.

The result about the CPD activities in the aspect of knowledge development conducted by senior secondary school mathematics teacher in Kulon Progo Regency based on the CPD implementation questionnaire is presented in the following Table 2.

Table 2

The CPD Implementation Based on Questionnaire

\begin{tabular}{llc}
\hline \multicolumn{1}{c}{ Indicator } & \multicolumn{1}{c}{ CPD's Activity } & Percentage Score \\
\hline $\begin{array}{l}\text { Professional } \\
\text { reading }\end{array}$ & $\begin{array}{l}\text { Reading literature related to mathematics content } \\
\text { Reading literature related to teaching, learning, or } \\
\text { education }\end{array}$ & $70.45 \%$ \\
& The mean of professional reading activity's score & $68.18 \%$ \\
& & $69.32 \%$ \\
Formal & Continuing formal education to magister or & $4.55 \%$ \\
education & doctoral degree & (Very Poor \\
& & Category) \\
\end{tabular}




\begin{tabular}{|c|c|c|}
\hline Indicator & CPD's Activity & Percentage Score \\
\hline \multirow[t]{4}{*}{$\begin{array}{l}\text { Professional } \\
\text { training }\end{array}$} & $\begin{array}{l}\text { Taking part in workshops, seminars or conferences } \\
\text { related to mathematics content }\end{array}$ & $23.48 \%$ \\
\hline & $\begin{array}{l}\text { Taking part in workshops, seminars or conferences } \\
\text { related to teaching, learning, or education }\end{array}$ & $22.73 \%$ \\
\hline & Taking part in professional learning communities & $45.83 \%$ \\
\hline & The mean of professional training activity's score & $\begin{array}{c}30.68 \% \\
\text { (Poor Category) }\end{array}$ \\
\hline \multicolumn{2}{|c|}{ The mean score of the aspect of knowledge development } & $\begin{array}{c}34.85 \% \\
\text { (Poor Category) }\end{array}$ \\
\hline
\end{tabular}

Table 2 shows that the CPD implementation in the aspect of knowledge development conducted by senior secondary school mathematics based on the questionnaire was poor (34.85\%). The details of the implementation for each indicator were:

(1) professional reading was fair $(69.32 \%)$;

(2) formal education was very poor $(4.55 \%)$; and

(3) professional training was poor $(30.68 \%)$.

Based on Table 3, it was found that the percentage score of the professional reading activity was higher than the other CPD activities.

The result of CPD implementation in the aspect of knowledge development conducted by Indonesian senior secondary school mathematics teacher in Kulon Progo Regency based on the CPD implementation documentation is presented in Table 3.

Table 3 shows that the CPD implementation in the aspect of knowledge development conducted by Indonesian senior secondary school mathematics based on documentation was poor $(25.97 \%)$. The details for each indicator were:

(1) professional reading was fair $(69.64 \%)$;

(2) formal education was very poor $(0 \%)$; and

(3) professional training was very poor $(8.27 \%)$.

Based on Table 3, it was found that the percentage score for the professional reading activity was higher than other CPD activities.

Table 3

The CPD Implementation Based on Documentation

\begin{tabular}{llc}
\hline \multicolumn{1}{c}{ Indicator } & \multicolumn{1}{c}{ CPD's Activity } & Percentage Score \\
\hline $\begin{array}{l}\text { Professional } \\
\text { reading }\end{array}$ & Reading literature related to mathematics content & $70.54 \%$ \\
& $\begin{array}{l}\text { Reading literature related to teaching, learning, or } \\
\text { education }\end{array}$ & $68.75 \%$ \\
& The mean of professional reading activity's score & $\begin{array}{c}69.64 \% \\
\text { (Fair Category) }\end{array}$
\end{tabular}




\begin{tabular}{llc}
\hline \multicolumn{1}{c}{ Indicator } & \multicolumn{1}{c}{ CPD's Activity } & Percentage Score \\
\hline $\begin{array}{l}\text { Formal } \\
\text { education }\end{array}$ & $\begin{array}{l}\text { Continuing formal education to magister or doctoral } \\
\text { degree }\end{array}$ & $\begin{array}{c}0 \% \\
\text { (Very Poor } \\
\text { Category) }\end{array}$ \\
$\begin{array}{ll}\text { Professional } \\
\text { training }\end{array}$ & $\begin{array}{l}\text { Taking part in workshops, seminars or conferences } \\
\text { related to mathematics content } \\
\text { Taking part in workshops, seminars or conferences } \\
\text { related to teaching, learning, or education } \\
\text { Taking part in professional learning communities }\end{array}$ & $12.68 \%$ \\
& $\begin{array}{l}\text { The mean of professional training activity's score } \\
\text { The mean of knowledge development aspect's score }\end{array}$ & $\begin{array}{c}0.00 \% \\
8.27 \% \\
\text { (Very Poor } \\
\text { Category) }\end{array}$ \\
\hline
\end{tabular}

From the interview data, we found that there were three categories:

(1) professional reading;

(2) continuing formal education to magister degree; and

(3) taking part in workshops, seminars, and professional learning communities.

Based on the results of the questionnaire and documentation, we gained information that professional reading was the most applied feature of the CPD activity conducted by teachers. These results were also supported by the results of the interview whereby professional reading was the found to be the easiest and most frequent activity conducted by teachers as part of their teaching preparation. Concerning this finding, studies such as Ambarita's study (2011) also suggested that teacher professional development by improving teachers' habits in reading can improve teachers' professional attitudes.

Related to the continuing formal education activity, teachers who continued formal education to master's degree said that they could update their knowledge by continuing formal education. Related to professional training, we found that teachers usually participated in training because they were assigned by their principals or they were invited by government educational institutions. The training' topics discussed were: curriculum implementations; The Indonesian National Exam (Ujian Nasional) discussion; developing lesson plans; mathematics learning assessment; developing mathematics teaching media; teaching methods and strategies; action research; and developing High Order Thinking problems. But, some teachers who had participated to training also said that they didn't implement their new knowledge to their teaching practices. Based on interview data, teachers stated several reasons why they did not implement their new knowledge, as follows: (1) their students were not suitable using various learning strategies and mathematics teaching media; (2) using mathematics teaching media in learning needed more time; and (3) some schools didn't have 
adequate infrastructure and facilities. Qablan, Mansour, Alshamrani, Sabbah, and Aldahmash (2015) reported from their study that most of the teachers in their sample said that they gained advantages by participating in CPD program, but there were only few teachers who implemented it in their classroom. Doherty's study (2011) showed that teachers who participated in workshops about learning technology gave positive feedback, but only few of the teachers who implemented it in their classroom. Wallace's study (2009) suggested that professional development affected student achievement when the effects of professional development were mediated by teacher practice. Therefore, we suspected that the effects of CPD towards student achievement depended upon whether the teacher implemented the new knowledge gained from the training.

Based on interview data, some teachers said that they received many advantages from Subject Teachers Discussion (Musyawarah Guru Mata Pelajaran), as a form of professional learning communities. The advantages were: (1) teachers could share their knowledge or experiences about teaching and learning; and (2) teachers could create social networking and this social networking helped teachers to get new information about training that will be held in the future. It can be said that Subject Teachers Discussion is one of the forms of CPD activities which was effective for improving teaching and learning quality for this group of teachers. Concerning this finding, studies such as Bolam, et al. (2005, p. 145) asserted that effective professional learning communities encourage teachers to participate actively in improving the quality of student learning. Vescio, Ross, and Adams (2008) suggested that professional learning communities had a positive impact upon both teaching practice and student achievement. Dunne, Nave, and Lewis (2000) found that the teaching practices of participants who belong to professional learning communities became more student-centred.

According to Desimone (2009), CPD can not only develop teachers' skills and knowledge, but can also change teachers' beliefs and attitudes. Hence, we also suspected that one of the reasons teachers' teaching practice didn't change because the teachers' beliefs and attitudes had not changed. Some studies have discussed the inconsistency between teachers' teaching practice and teachers' beliefs (Barkatsas \& Malone, 2005; Wilkins, 2008; Lopes \& Santos, 2013).

Future suggested research could seek to analyse the reasons teachers' why the teaching practice didn't change, even though teachers had participated to CPD in knowledge development.

\section{The CPD Implementation Barriers in Knowledge Development Aspect}

The results about the CPD barriers faced by Indonesian senior secondary school mathematics teacher in Kulon Progo Regency in the aspect of knowledge development based on the CPD questionnaire is presented in Table 4. It shows that the greatest barriers experienced by teachers related to the teachers' overwhelming workload (93.94\%), a lack of self-motivation (93.94\%), and inadequate place and time (87.88\%).

Based on the interview data a similar result to the questionnaire data occurred, and so the study found that most of the teachers could not continue formal education or take part in professional training or development because of an overwhelming workload, a lack of self- 
motivation, and an inadequate place and time. Other studies have reported similar results regarding CPD barriers. Kennedy and McKay, (2011) reported that their results indicated that the early-career teachers have a wide range of different needs, in terms of both content and mode of CPD, yet they do not appear to feel strongly about barriers to their participation. While David and Bwisa (2013) said the researchers also used descriptive statistics and the results were presented in frequency distribution tables which were used for the purposes of interpretation. The findings from their study showed that few teachers were actively involved in continuous professional development in the district and that in harmony with the results of this current study, the teachers' work environment did not support the teachers' involvement in CPD.

Table 4

The CPD Barriers Faced by Teachers Based on Questionnaire

\begin{tabular}{lc}
\hline Barriers & $\begin{array}{c}\text { Percentage of } \\
\text { Teachers Facing Barriers }\end{array}$ \\
\hline Overwhelming workload & $93.94 \%$ \\
Lack of self-motivation & $93.94 \%$ \\
Inadequate place and time & $87.88 \%$ \\
Lack of English proficiency for reading English literature & $72.73 \%$ \\
Inadequate literature & $57.58 \%$ \\
Financial cost & $42.42 \%$ \\
Lack of school supports (principal, colleagues, financial) & $36.36 \%$ \\
Lack information about trainings & $21.21 \%$ \\
No assignment from principal or training invitation & $6.06 \%$ \\
Lack information about university & $3.03 \%$ \\
\hline
\end{tabular}

\section{Conclusion}

CPD has a crucial role in the development of teacher competencies. CPD can also contribute to student achievement when teachers' knowledge and experiences are mediated by teachers' teaching practice. The results of this study showed that the CPD implementation in the aspect of knowledge development of Yogyakarta senior secondary school mathematics teachers in Kulon Progo Regency was poor. The greatest barriers experienced by teachers related to conducting the aspect of knowledge development were an overwhelming workload, a lack of self-motivation, and an inadequate place and time.

Due to the sample limitations of this study, the findings can only apply to the teachers in the sample and cannot be regarded as representing a wider group of Indonesia teachers. However, the finding can be of interest to teachers and educators in making comparisons with their own situation.

The finding in this study suggest that teachers in the sample need to be helped to develop their understanding and awareness of how CPD can improve their competencies, teaching practice quality, and student achievement. Teachers in the sample also need to be supported to develop their knowledge through reading, continuing formal education, and 
taking part in professional training. We also suggest that the government and stakeholders should encourage and facilitate teachers in the sample to participate actively in CPD activities that seek to fulfil teachers' need.

We also suggest that future research studies are needed to analyse the relationship between CPD, teachers' knowledge, teachers' beliefs, teachers' practices, and student achievement.

\section{References}

Ambarita, B. (2011). Upaya peningkatan sikap profesional guru melalui peningkatan kebiasaan membaca. Cakrawala Pendidikan, XXX(2), 314-325.

Andriani, D, E. (2012). Program peningkatan mutu guru berbasis kebutuhan. Jurnal Manajemen Pendidikan, 23(5), 395-402.

Bailey, M. (2011). Policy, professionalism, professionality and the development of HR practitioners in the UK. Journal of European Industrial Training, 35(5), 487-501. doi: $10.1108 / 03090591111138035$

Barkatsas, T. A., \& Malone, J. (2005). A typology of mathematics teachers' beliefs about teaching and learning mathematics and instructional practices. Mathematics Education Research Journal, 17, 69-90.

Bolam, R., McMahon, A., Stoll, L., Thomas, S., Wallace, M., Greenwood, A., et al. (2005). Creating and sustaining effective professional learning communities. London: University of Bristol.

Bubb, S., \& Early, P. (2007). Leading and managing continuing professional development ( $2^{\text {nd }}$ ed.). London: Paul Chapman Publishing.

Buddin, R. and Zamarro, G. (2009). Teacher qualifications and student achievement in urban elementary schools. Journal of Urban Economic, 66, 103-115. doi: 10.1016/j.jue.2009.05.001.

Collin, K., van der Heijden, B., \& Lewis, P. (2012). Continuing professional development. International Journal of Training and Development, 16(3), 155-163. doi: 10.1111/j.1468-2419.2012.00410.x.

Creswell, J. W. (2012). Educational research: Planning, conducting, and evaluating quantitative and qualitative research (4 ${ }^{\text {th }}$ ed.). Boston, MA: Pearson.

Croft, A., Coggshall, J. G., Dolan, M., Powers, E, and Killion, J. (2010). Job-embedded professional development: What it is, who is responsible, and how to get it done well. Washington, DC: National Comprehensive Center for Teacher Quality.

Darling-Hammond, L. (2000). Teacher quality and student achievement: A review of state policy evidence. Education Policy Analysis Archives, 8(1), 1-44.

David, M. N., \& Bwisa, H. M. (2013). Factors influencing teachers' active involvement in continuous professional development: A survey in Trans Nzoia West District, Kenya. International Journal of Academic Research in Business and Social Sciences, 3(5), 224235.

Day, C. (2002). Developing teachers: The challenges of lifelong learning. London: Taylor \& Francis. 
Desimone, L. M. (2009). Improving impact studies of teachers' professional development: Toward better conceptualizations and measures. Educational Researcher, 38(3), 181199. doi: 10.3102/0013189X08331140.

Desimone, L. M., Porter, A. C., Garet, M. S., Yoon, K. S., \& Birman, B. F. (2002). Effects of professional development on teachers' instruction: Results from a three-year longitudinal study. Educational Evaluation and Policy Analysis, 24(2), 81-112.

Doherty, I. (2011). Evaluating the impact of professional development on teaching practice: Research findings and future research directions. US-China Education Review, 5, 703714.

Dunne, F. Nave, B., \& Lewis, A. (2000). Critical friends groups: Teachers helping teachers to improve student learning. [Online] Available: http://www.schoolreforminitiative.org/wpcontent/uploads/2014/02/Dunne_et_al_2000.pdf [2018, April 15].

Guskey, T. R., \& Sparks, D. (2000). Evaluating professional development. Thousand Oaks, CA: Corwin Press.

Hill, H. C., Rowan, B., and Ball, D. L. (2005). Effects of teachers' mathematical knowledge for teaching on student achievement. American Educational Research Journal Summer, 42(2),371-406.

Kennedy, A., \& McKay, J. (2011). Beyond induction: the continuing professional development needs of early-career teachers in Scotland. Professional Development in Education, 37(4), 551-569. doi: 10.1080/19415257.2010.533598

Lopes, J., \& Santos, M. (2013). Teachers' beliefs, teachers' goals and teachers' classroom management: A study with primary teachers. Revista de Psicodidáctica, 18, 5-24.

Miles, M. B., \& Huberman, A. M. (1994). Qualitative data analysis: An expanded sourcebook ( $2^{\text {nd }} e d$.). Thousand Oaks, CA: Sage Publications.

Ministry of National Education. (2010a). Pembinaan dan pengembangan profesi guru buku 1: Pedoman pengelolaan pengembangan keprofesian bekelanjutan (PKB). Jakarta: Direktorat Jenderal Peningkatan Mutu dan Tenaga Kependidikan.

Ministry of National Education. (2010b). Pembinaan dan pengembangan profesi guru buku 4: Pedoman kegiatan pengembangan keprofesian berkelanjutan (PKB) dan angka kreditnya. Jakarta: Direktorat Jenderal Peningkatan Mutu dan Tenaga Kependidikan.

Mitkovska, S. S. (2010). The need of continuous professional teacher development. Procedia Social and Behavioral Sciences, 2, 2921-2926. doi: 10.1016/j.sbspro.2010.03.441.

Opfer, V. D. \& Pedder, P. (2010). Benefits, status and effectiveness of continuous professional development for teachers in England. The Curriculum Journal, 21(4), 413431. doi: $10.1080 / 09585176.2010 .529651$.

Ozdemir, S. M. (2013). Exploring the turkish teachers' professional development experiences and their needs for professional development. Mevlana International Journal of Education, 3(4), 250-264.

Powell, E. D., Furey, S., \& Scott-evans, A. (2003). Teachers' perceptions of the impact of CPD: An institutional case study. Journal of In-service Education, 29(3), 389-404. 
Qablan, A. M., Mansour, N., Alshamrani, S., Sabbah, S., \& Aldahmash, A. (2015). Ensuring effective impact of continuing professional development: Saudi science teachers' perspective. Eurasia Journal of Mathematics, Science \& Technology Education, 11(3), 619-631. doi: https://doi.org/10.12973/eurasia.2015.1352a

Rahmat, A, Amprasto, Riandi, \& Sutarno, N. (2011). Profil program continuous professional development (CPD) guru biologi di wilayah jawa barat dalam upaya meningkatkan kualitas profesi. Jurnal Pengajaran MIPA, 16(1), 155-163.

Rockoff, J. E. (2004). Association the impact of individual teachers on student achievement: Evidence from panel data author. The American Economic Review, 94(2), 247-252. doi: $10.1257 / 0002828041302244$

Shah, F. H., Khan, U. A., \& Ahmed, I. (2015). The impact of continuous professional development (CPD) program on teachers' professional development in Pakistan. $F W U$ Journal of Social Sciences, 9(1), 99-105.

Stronge, J. H., Ward, T. J., Tucker, P. D., \& Hindman, J. L. (2007). What is the relationship between teacher quality and student achievement? An exploratory study. Journal of Personnel Evaluation in Education, 20(3), 165-184, doi: 10.1007/s11092-008-9053-z.

Sujianto. (2013). Pengembangan profesionalitas berkelanjutan/Continuing Professionality Development (CPD) guru bersertifikat pendidik di smk rumpun teknologi se-malang raya. Jurnal Pendidikan Sains, 1(2), 159-170.

Tchoshanov, M. A. (2011). Relationship between teacher knowledge of concepts and connections, teaching practice, and student achievement in middle grades mathematics. Educational Studies in Mathematics, 76(2), 141-164.

Vescio, V., Ross, D., \& Adams, A. (2008). A review of research on the impact of professional learning communities on teaching practice and student learning. Teaching and Teacher Education, 24, 80-91. doi:10.1016/j.tate.2007.01.004.

Wallace, M. (2009). Making Sense of the Links: Professional Development. Teacher Practices. Teachers College Record Volume 111(2), 573-596. Retrieved from: $\mathrm{https}: / / \mathrm{msu} . \mathrm{edu} / \sim$ wallacem/MARCY/PUBLICATION/_\%20Making\%20Sense\%20of\%2 0the $\% 20$ Links...pdf.

Wibowo, E. \& Jailani. (2014). Analisis kesulitan guru matematika SMP dalam pengembangan profesi di kabupaten wonosobo. Jurnal Riset Pendidikan Matematika, $1(2), 202-215$.

Wilkins, J. L. M. (2008). The relationship among elementary teachers' content knowledge, attitudes, beliefs, and practices. Journal of Mathematics Teacher Education, 11, 139-64. 